\title{
RESEARCHPAPER
}

\section{Growth and productivity of beet root (Beta vulgaris L.) with monetary returns as affected by different spacings}

\author{
ANJALI M. GAHARWAR ${ }^{1}$, JAYASHRI D. UGHADE ${ }^{2}$ AND NILIMA V. PATIL ${ }^{1}$ \\ ${ }^{1}$ Krishi Vigyan Kendra (Dr. P.D.K.V.), YAVATMAL (M.S.) INDIA \\ ${ }^{2}$ Vasantrao Naik College of Agricultural Biotechnology (Dr. P.D.K.V.), YAVATMAL (M.S.) INDIA
}

Article Info : Received : 03.05.2017; Revised : 16.08.2017; Accepted : 14.09.2017

To find out optimum spacing on growth and productivity of beet root and to standardize package of practices for beet root cultivation in Vidarbha region with monetary return a field experiment was undertaken during the winter seasons of three consecutive years. The experiment was conducted in a Randomized Block Design at the farm of Agricultural Research Station (Dr. PDKV), Yavatmal. On the basis of spacing, plants were transplanted at two row spacing viz., $30 \mathrm{~cm}$ and $45 \mathrm{~cm}$ and in row three plant to plant spacing viz., $10 \mathrm{~cm}, 20 \mathrm{~cm}$ and $30 \mathrm{~cm}$ with one separate $45 \mathrm{~cm} \mathrm{x} 45 \mathrm{~cm}$ wider spacing plot with three replications. The result indicated that closer plant spacing had significantly increased plant height however, wider plant spacings significantly increased plant spread, number of leaves and weight of beet root. Further the closer plant spacing found significantly higher marketable quality beet root yield with highest net monetary returns.

Key words : Plant spacing, Yield, Beta vulgaris, Growth, Productivity, NMR

How to cite this paper : Gaharwar, Anjali M., Ughade, Jayashri D. and Patil, Nilima V. (2017). Growth and productivity of beet root (Beta vulgaris L.) with monetary returns as affected by different spacings. Asian J. Bio. Sci., 12 (2) : 189-193.DOI : 10.15740/HAS/AJBS/12.2/189193. 